\title{
NEWSPAPER COVERAGE OF ISSUE-BASED POLITICAL STATEMENTS AND CAMPAIGNS IN NIGERIA'S ELECTORAL PROCESS (NOVEMBER 2018 - FEBRUARY 2019)
}

\author{
Emmanuel Ikpegbu (a), Walter Ihejirika (b) \\ (a) University of Port Harcourt. Port Harcourt, Nigeria. Email: emmanuelikpegbu[at]gmail.com \\ (b) University of Port Harcourt. Port Harcourt, Nigeria. Email: walter.ihejirika[at]uniport.edu.ng
}

\begin{abstract}
The electoral process in Nigeria is now more dynamic than in earlier years because of the nature of competitions among politicians. In a bid to sell candidates and woo voters, political parties engage in election campaigns during which statements are made. Campaigns ought to address issues of public importance, but in some instances the comments are mere expressions of personal sentiments. The press is not just the fourth estate of the realm but also the voice of the people to report issues for voters' enlightenment. This paper examined newspaper coverage of issue-based political statements and campaigns in Nigeria's 2019 electoral process. Two theoretical frameworks for the study were Agenda Setting Theory and Development Media Theory. The study was both quantitative and qualitative, covering newspaper reports from two national dailies, Vanguard and The Punch. A total of 76 editions were studied using the content analysis research design, with quoted statements buttressing the argument. The data were presented with frequency tables and analysed through simple percentages. There were 116 reports on the subject in the dailies. The paper found out that while there were coverage over some national issues like restructuring, security, corruption, economy, and electricity, the greater volume of political statements were not issue-based. There is the need for the press to pay less attention on matters that would not serve to educate voters adequately. The study recommends that the press use the editorials to canvass for issue-based comments. The study also contributed to knowledge as the seminal analysis of political statements in 2019 general elections.
\end{abstract}

\section{Keywords}

electoral process; election campaign; issue-based; political statements; media; Nigeria

This work is licensed under a Creative Commons «Attribution» 4.0 International License. 


\section{ОСВЕЩЕНИЕ В ГАЗЕТАХ ПОЛИТИЧЕСКИХ ЗАЯВЛЕНИЙ И КАМПАНИЙ, ОРИЕНТИРОВАННЫХ НА ПРОБЛЕМЫ ОБЩЕСТВЕННОЙ ВАЖНОСТИ, В ИЗБИРАТЕЛЬНОМ ПРОЦЕССЕ В НИГЕРИИ (НОЯБРЬ 2018 ГОДА - ФЕВРАЛЬ 2019 ГОДА)}

\section{Икпегбу Эммануэль (a), Ихеджирика Вальтер (b)}

(а) Университет Порт Харкорт. Порт Харкорт, Нигерия. Email: emmanuelikpegbu[at]gmail.com

(b) Университет Порт Харкорт. Порт Харкорт, Нигерия. Email: walter.ihejirika[at]uniport.edu.ng

\section{Аннотация}

Избирательный процесс в Нигерии сейчас более динамичный, чем в предыдущие годы, благодаря характеру соревновательности среди политиков. В попытке продать кандидатов и привлечь голоса избирателей политические партии участвуют в избирательных кампаниях, в ходе которых делаются заявления. Кампании должны ориентироваться на проблемы общественной важности, но в некоторых случаях комментарии являются лишь выражением личных настроений. Пресса - это не только четвертая власть в мире, но и голос людей, которые сообщают о своих проблемах для информиравания/просвещения избирателей. Эта статья рассматривает освещение в газетах тематических политических заявлений и кампаний в ходе избирательного процесса в Нигерии в 2019 году. В теоретическом плане формат исследования задан двумя рамками - Теории постановки повестки дня и Теории для медиа периода развития. В работе использовались как количественные, так и качественные методы; исследование охватывало газетные сообщения двух национальных ежедневных газет, Vanguard и The Punch. В общей сложности были изучены 76 изданий с использованием контент-анализа; при этом цитируемые высказывания подтверждали выдвинутые положения. Данные были представлены с помощью частотных таблиц и проанализированы с использованием простых процентов. В газетах было найдено 116 сообщений на интересующую нас тему. В статье показано, что, хотя некоторые национальные проблемы, такие как реструктуризация, безопасность, коррупция, экономика и электричество в газетах освещались, однако значительно больший объем политических заявлений не был основан на конкретном материале. Необходимо, чтобы пресса уделяла меньше внимания вопросам, которые не могут адекватно информировать избирателей. В нашей работе рекомендуется, чтобы пресса использовала редакционные статьи для организации комментирования общественноважных тем. Исследование также внесло свой вклад в академические знания как оригинальный первоначальный анализ политических заявлений на всеобщих выборах 2019 года.

\section{Ключевые слова}

избирательный процесс; избирательная кампания; проблемно-ориентированные; политические заявления; медиа; Нигерия

Это произведение доступно по лицензии Creative Commons «Attribution» («Атрибуция») 4.0 Всемирная 


\section{OVERVIEW}

Prior to the 2019 elections, the political space in Nigeria was marked by mixed feelings and realities because for many citizens, the government had not met their yearnings. The poor economic state of the people and the ailing economy of the nation, the rampant spate of killings by herdsmen and Boko Haram terrorists in the North as well as pockets of crime is several parts of the South, raised much concern. In South-East, there was the growing agitation against marginalisation by citizens and groups like the Independent People of Biafra (IPOB), who called for secession. And virtually every geopolitical zone clamoured for restructuring. But amidst these scenes, the administration of President Muhammadu Buhari believed that it had done very much in the country to improve the economy, improve security and fight against corruption. And the government had confidence going into the general elections.

Electioneering campaigns are expected to be issue-based because through it the electorate makes decisions. Some have argued that the atmosphere of the last election was explosive (Sobowale, 2019). The campaigns was officially declared open by the Independent National Electoral Commission (INEC), on November 18, 2019, but prior to that date, there had been efforts and statements to woo voters through rallies and other forums. It was declared by the electoral umpire that both parties and candidates should conduct themselves in organised, peaceful, rancor-free, hate and/or inflammatory speeches-free way (Egburonu \& Odufowokan, 2018).

But, rather than address burning issues in the country and sell opinions on how to better the country, politicians and their parties were often seen speaking of non-issue-based matters. Chief among the parties and politicians were the presidential candidates of the leading All Progressive Congress (APC), President Muhammadu Buhari and the main opposition party, Peoples Democratic Party (PDP), Alhaji Atiku Abubakar. The candidates' campaign organs were found expressing venoms against each other through name calling, allegations, insults, etc. (Iheanacho, 2019).

One of the forms of statements made during political campaigns is hate speech. Hate can be referred to as the use of discriminatory sobriquet to malign, stigmatise or abuse someone or people on the grounds of origin, socio-economics, religion, association etc. through verbal expression, demonstrative actions, written content that would cause others to engage in negative attitude towards the object (Adibe, 2015). Because of one's background, orientation or intention, hate can be demonstrated towards 
such and whenever there is a denigrating communication in that wise, Kukah (2015) believes that there is hate speech. The effect of every hate speech is disaffection towards the person or group referred to. And it is the belief of Mrabure (2016) that necessary steps need to be taken to discourage hate speech because besides its direct effects on the 'hated', the populace are likely to suffer from denial of freedom of expression through it.

Sometimes, the statements made by politicians may not even be hate speech but could be claims on things they would not fulfill. They often look at the pressing needs of the people and make promises that cannot not be kept. One of such borders on gender equality in governance. It is believed that women are not well represented in the political space and the present call is even for quota participation (Okorie, 2016; Olatunde, 2010; Audu, 2008). It is therefore usual to hear statements reassuring the female voting strength. Anorue, Obayi and Onyebuchi (2012) believe that attention should be sincerely accorded to women in the polity.

While there are several institutions in the society that wields much influence, the role of the press in determining what takes place in the country cannot be overemphasised. It can mould the form of political issues and actors through the nature of its communication to the audience. Here is the critical role of agenda setting the press stands to play (Davaney, 2013). The reason for such an understanding is not farfetched. People could perceive individuals, institutions or government in the direction the press portrays it. Hampl (2017) puts it this way: "The representation of social actors could indicate in what way particular parties, camps, or individuals are portrayed in discourse" (p. 56). The press stand as the voice of the masses and what they publish has a lot of impact. In many instances, media could decide to focus attention on certain issues such that it becomes a national subject. They could also silence an aspect of development that they do not find worthy of public knowledge. This is why Chiluwa (2011) espouses the understanding of the press having the power to conceal facts or reveal secrets.

\section{STUDY OBJECTIVES}

The aim of this paper was to ascertain newspaper coverage of issuebased political statements and campaigns in Nigeria's politics from November 2018 to February 2019. The specific objectives were to:

1. Find out the frequency of stories on issue-based political statements and campaigns in Nigeria's politics in the dailies; 
2. Identify the types of reports on issue-based political statements and campaigns in Nigeria's politics in the newspapers;

3. Ascertain the different kinds of political statements and campaigns in Nigeria's politics in newspapers;

4. Find out the placement of stories on issue-based political statements and campaigns in Nigeria's politics in the newspapers; and

5. Ascertain the directionality of newspaper reports on issue-based political statement and campaigns in Nigeria's politics.

\section{RESEARCH QUESTIONS}

1. How frequent were stories on issue-based political statements and campaigns in Nigeria's politics in the dailies?

2. What are the types of reports on issue-based political statements and campaigns in Nigeria's politics in the newspapers?

3. What are the different kinds of political statements and campaigns in Nigeria's politics in newspapers?

4. How were the stories on issue-based political statements and campaigns in Nigeria's politics placed in the newspapers?

5. What is the directionality of newspaper reports on issue-based political statements and campaigns in Nigeria's politics?

\section{THEORETICAL FRAMEWORK}

It is a common belief in the communication world that the press can actually construct news to form a worldview for the audience (Wahl-Jorgensen \& Hanitzch, 2009). This is due to the place of the media in setting agenda for the audience. The agenda setting theory, being one of the most popular frameworks in media studies, originated from the ideas of Walter Lippman's Public Opinion of 1922; theorised by Bernard Cohen in 1963 and crystalised by Maxwell McCombs and Donald Shaw in 1972 (McQuail, 2010; Baran \& Davies, 2009). The understanding is that what the media presents to the public is often taken as issues that worth attention and becomes the audience agenda at the long run.

On the other hand, Development Media Theory was propounded by Dennis McQuail in 1987 to espouse the place of the press in societies. It is an extension of the earlier forms of the Normative Theories to include the roles that developing nations' media have to play to bring about the needed positive change in the society (Anaeto, Onabanjo \& Osifeso, 2008). It is believed that the press owe the country a statutory responsibility to carry out development activities that are in tandem with the laws and 
policies established in the land. Thus, the media have freedom and responsibilities not only to inform, but to inform properly; not just to educate, but to educate effectively; not just to entertain, but to entertain intelligently. It thus deals with press behaviour.

These theories are cogent because the agenda setting theory draws attention to the press' role of bringing important issues to public discussion while the development media theory demands responsible journalism from the media.

\section{ISSUES IN NIGERIA AND ELECTION CAMPAIGNS}

Election takes place in a politically charged atmosphere where citizens prepare themselves to perform their constitutional roles by voting (Musbeh, 2018). Political parties have been described as indispensable means for representative democracies (Pippa, 2005), bearing in mind that the democratic system is made up of the agencies like political parties which make democracy feasible as the loop for governance (IDEA, 2017). And in many countries, a multiparty system is adopted in which more than two political parties contest in elections. It is therefore necessary to strengthen political parties in every society (Sete, 2018). Given that democracy is a ground order of political legitimacy in the society, politicians make every attempt to sway voters (Held, 2006; Adeleke, 2006) during electioneering campaigns. Thus, statements made are often aimed at galvanising support.

The 2019 general elections in Nigeria witnessed another round of political campaigns which availed politicians the opportunity to inform the electorates what they would do if voted into power. Unlike the 2015 general elections when there were only 14 presidential candidates, the last election had 73 of them vying for the exalted seat. But the contest was basically between APC and PDP. Among the issues that faced the nation and demanded for attention were those of security, anti-corruption fight, economy, unemployment, electricity, job creation, and restructuring. It is believed that the ability to address these could influence voting (Egburonu \& Odufowokan, 2018; Unah, 2019).

\section{THE PRESS AND REPORTAGE OF POLITICAL STATEMENTS}

There is an enormous role that is expected of the press in the democratic process of Nigeria. Iredia (2007) puts it this way: "The people must be assisted to premise their choices of rationality and vote wisely during elections. They must have all information that is needed to elect the right candidates who can ensure good governance". He also added, "Where 
such public awareness is lacking, those of us in the media must accept a share of the blame of failed elections in Nigeria" (p. 12). It is therefore important that the press do not just pass information to the public as much as it evolves, but that they go further in analysing the reports for readers' appreciation as well as focusing on relevant issues.

The objective of reporting political statements and campaigns is to enable voters who rely on the press to become very much acquainted with the candidates and parties in order to make informed decisions at the poll for good governance (Dimitrova, Sheheta, Stromback \& Nord, 2014; Carkoglu, Baruh \& Yildirim, 2014). The understanding of many scholars and analysts today is that it is unthinkable to hold elections in contemporary times without the contribution of the media (Ace Project, 2012; Ibrahim, Ogwezzy-Ndesikka \& Tejumaiye, 2015).

In their study, Asiru, Ogutu and Orwenjo (2018) found out that there was bias in newspaper reportage of political parties and candidates in the 2011 elections. While a particular party, the ruling party was projected positively, the main opposition was presented negatively as other contending parties were accorded least attention. Again, Ojebuyi and Chukwunwike (2018) found out that female politicians receive less attention in Nigerian newspaper reportage compared to male folk who had more coverage and prominence in the publications. In a study championed by BusinessDay Media and NOIPolls in November 2014, it was found out that:

More than half (57\%) of the Nigerian adult population believe political campaigns are not focusing on current issues in the country; this perception cuts across all regions, although residents of North-West zone maintained a different perspective as the majority in this region believe the campaigns of politicians are focused on addressing the present issues. In line with this, a significant proportion (48\%) of Nigerians stated politicians should focus on addressing security in their campaigns to make meaningful impact. This stance was mostly maintained by residents of the North-East (70\%) and North-West (62\%) given the current state of insecurity in these regions. Job Creation and Education were also considered as priority for focus among other areas...A view of the pressing issues in Nigeria demonstrates Education (67\%) as the most pressing national issue that needs to be tackled, followed by Electricity (39\%), Infrastructure (38\%), and Water (34\%), among others; even though Nigerians believe current campaigns should focus on security (NOI Polls, 2015).

The implications of the above are that while the press could be biased, previous electioneering processes witnessed much of non-issuebased statements because the campaigns where not development focused. The 2019 election presents another opportunity to evaluate the experience by understanding what was portrayed in the newspapers. 


\section{METHODOLOGY}

This study was conducted through the content analysis research method because it focused on press coverage of political statements made towards the 2019 general elections in Nigeria. This method is recommended for media contents (Kerlinger, 2000). The study population is comprised of all national dailies from which Vanguard and Punch were sampled. Both dailies have national circulation and credibility. The study covered three months: November 2018, January and February 2019. These months marked the official launching of the political campaign and its closing. The study designed a code sheet and a code guide for data gathering in which it had the unit of analysis as story type, issue-based, non-issue-based, placement, frequency, and directionality. The content categories included security, economy, job creation, infrastructure, education, water supply, electricity, health, restructuring, agriculture, road/transport, anticorruption, industrialization, and 'others' as issue-based indicators whereas name-calling, allegations, and partisanship formed the non-issue-based indicators. Monday, Wednesday and Friday, were adopted to form a composite week. There were a total 76 publications from both dailies within the period of the study. In the presentation and analysis of data, the study employed tables and simple percentages for clarity.

\section{PRESENTATION AND ANALYSIS OF DATA}

Research Question One: How frequent were stories on issue-based political statements and campaigns in Nigeria's politics in the dailies?

\begin{tabular}{|c|c|c|c|c|c|c|c|}
\hline \multirow[b]{3}{*}{ Item } & \multicolumn{6}{|c|}{ Period } & \multirow[b]{3}{*}{ Total } \\
\hline & \multicolumn{2}{|c|}{ November } & \multicolumn{2}{|c|}{ January } & \multicolumn{2}{|c|}{ February } & \\
\hline & $\begin{array}{r}\text { No. } \\
\text { Published } \\
\text { Stories }\end{array}$ & $\begin{array}{r}\text { Percent } \\
(\%)\end{array}$ & $\begin{array}{c}\text { No. } \\
\text { Published } \\
\text { Stories }\end{array}$ & $\begin{array}{r}\text { Percent } \\
(\%)\end{array}$ & $\begin{array}{r}\text { No. } \\
\text { Published } \\
\text { Stories }\end{array}$ & $\begin{array}{r}\text { Percent } \\
(\%)\end{array}$ & \\
\hline Vanguard & 21 & $48.8(36.2)$ & 19 & $\begin{array}{r}45.2 \\
(32.7)\end{array}$ & 18 & $58.06(31)$ & 58 \\
\hline Punch & 22 & $51.2(37.9)$ & 23 & $\begin{array}{r}54.8 \\
(39.7) \\
\end{array}$ & 13 & $41.9(22.4)$ & 58 \\
\hline Total & 43 & $\begin{array}{r}100 \\
(37.06)\end{array}$ & 42 & $\begin{array}{r}100 \\
(36.2)\end{array}$ & 31 & $100(26.7)$ & 116 \\
\hline
\end{tabular}

Table 1: Frequency of Reports on Political Statements

Table 1 reveals that there were more political statements before the election date given that it recorded constant decline in the number of reported statements, from $37.06 \%$ in November 2018 to 26.7\% in February, 
2019, which was the period of the election. Thus, it can be said that when the election drew closer, politicians focused more on actions than words.

Research Question Two: What are the types of reports on issuebased political statements and campaigns in Nigeria's politics in the newspapers?

\begin{tabular}{|c|c|c|c|c|c|c|}
\hline \multirow[b]{2}{*}{ Type of Story } & \multicolumn{2}{|c|}{ Vanguard } & \multicolumn{2}{|c|}{ Punch } & \multirow[b]{2}{*}{ Total } & \multirow[b]{2}{*}{$\begin{array}{c}\text { Percent } \\
(\%)\end{array}$} \\
\hline & $\begin{array}{c}\text { No. } \\
\text { Report }\end{array}$ & $\begin{array}{c}\text { Percent } \\
(\%)\end{array}$ & $\begin{array}{c}\text { No. } \\
\text { Report }\end{array}$ & $\begin{array}{c}\text { Percent } \\
(\%)\end{array}$ & & \\
\hline Straight news & 57 & 98.27 & 58 & 100 & 115 & 99.1 \\
\hline Letters & 0 & 0 & 0 & 0 & 0 & 0 \\
\hline $\begin{array}{l}\text { Cartoons/ } \\
\text { pictures/Ad }\end{array}$ & 0 & 0 & 0 & 0 & 0 & 0 \\
\hline Opinion article & 0 & 0 & 0 & 0 & 0 & 0 \\
\hline Features & 1 & 1.7 & 0 & 0 & 1 & 0.86 \\
\hline Editorial & 0 & 0 & 0 & 0 & 0 & 0 \\
\hline Total & 58 & 100 & 58 & 100 & 116 & 100 \\
\hline
\end{tabular}

Table 2: Story types on Political Statements

The data in Table 2 reveals that almost all the statements made were reported as straight news in the dailies. Only one features had a statement.

Research Question Three: What are the different kinds of political statements and campaigns in Nigeria's politics in newspapers?

\begin{tabular}{|c|c|c|c|c|c|c|c|c|c|c|c|}
\hline \multirow[b]{2}{*}{$\begin{array}{l}\text { Issue } \\
\text { Indicator }\end{array}$} & \multicolumn{3}{|c|}{ November } & \multicolumn{3}{|c|}{ January } & \multicolumn{3}{|c|}{ February } & \multirow[b]{2}{*}{$\begin{array}{l}\text { Cum. } \\
\text { Total }\end{array}$} & \multirow{2}{*}{$\begin{array}{c}\text { Per } \\
\text { cen } \\
t \\
(\%)\end{array}$} \\
\hline & $\begin{array}{c}\text { Vangu } \\
\text { ard }\end{array}$ & $\begin{array}{c}\text { Pun } \\
\text { ch }\end{array}$ & $\begin{array}{r}\text { To } \\
\text { tal }\end{array}$ & $\begin{array}{l}\text { Vangu } \\
\text { ard }\end{array}$ & $\begin{array}{c}\text { Pun } \\
\text { ch }\end{array}$ & $\begin{array}{l}\text { To } \\
\text { tal }\end{array}$ & $\begin{array}{l}\text { Vangu } \\
\text { ard }\end{array}$ & $\begin{array}{l}\text { Pun } \\
\text { ch }\end{array}$ & $\begin{array}{l}\text { To } \\
\text { tal }\end{array}$ & & \\
\hline Security & 2 & 3 & 5 & 1 & 1 & 2 & 1 & 1 & 2 & 9 & 7.75 \\
\hline Economy & 2 & 3 & 5 & 2 & 1 & 3 & 0 & 1 & 1 & 9 & 7.75 \\
\hline Job creation & 0 & 1 & 1 & 0 & 0 & 0 & 0 & 0 & 0 & 1 & 0.86 \\
\hline Infrastructure & 0 & 0 & 0 & 0 & 0 & 0 & 0 & 0 & 0 & 0 & 0 \\
\hline Education & 0 & 1 & 1 & 0 & 0 & 0 & 0 & 0 & 0 & 1 & 0.86 \\
\hline Water supply & 0 & 0 & 0 & 0 & 0 & 0 & 0 & 0 & 0 & 0 & 0 \\
\hline Electricity & 0 & 0 & 0 & 0 & 0 & 0 & 0 & 0 & 0 & 0 & 0 \\
\hline Health & 0 & 0 & 0 & 1 & 0 & 1 & 0 & 0 & 0 & 1 & 0.86 \\
\hline Restructuring & 2 & 2 & 4 & 1 & 1 & 2 & 1 & 0 & 1 & 7 & 6.03 \\
\hline Agriculture & 0 & 0 & 0 & 0 & 0 & 0 & 0 & 0 & 0 & 0 & 0 \\
\hline $\begin{array}{l}\text { Road/ } \\
\text { Transport }\end{array}$ & 0 & 0 & 0 & 0 & 0 & 0 & 1 & 1 & 2 & 2 & 1.7 \\
\hline $\begin{array}{l}\text { Anti- } \\
\text { corruption }\end{array}$ & 0 & 0 & 0 & 0 & 0 & 0 & 0 & 0 & 0 & 0 & 0 \\
\hline
\end{tabular}




\begin{tabular}{lccccccccccc}
$\begin{array}{l}\text { Industrializatio } \\
\mathrm{n}\end{array}$ & 0 & 0 & 0 & 0 & 0 & 0 & 0 & 0 & 0 & 0 & 0 \\
$\begin{array}{l}\text { Other issue- } \\
\text { based }\end{array}$ & 3 & 2 & 5 & 3 & 2 & 5 & 4 & 4 & 8 & 18 & 15.5 \\
Name-calling & 7 & 2 & 9 & 5 & 2 & 7 & 2 & 1 & 3 & 19 & 16.4 \\
Allegations & 2 & 6 & 8 & 2 & 8 & 10 & 3 & 4 & 7 & 25 & 21.5 \\
Partisanship & 4 & 4 & 8 & 4 & 5 & 9 & 5 & 2 & 7 & 24 & 20.7 \\
\hline Total & $\mathbf{2 2}$ & $\mathbf{2 4}$ & $\mathbf{4 6}$ & $\mathbf{1 9}$ & $\mathbf{2 0}$ & $\mathbf{3 9}$ & $\mathbf{1 7}$ & $\mathbf{1 4}$ & $\mathbf{3 1}$ & $\mathbf{1 1 6}$ & $\mathbf{1 0 0}$ \\
\hline
\end{tabular}

Table 3: Kinds of Statements (Indicators) on Political Statements

Table 3 illustrates that some issues were not reported in the headlines of the newspapers within the period under review. Among such were infrastructure, water supply, electricity, agriculture, anti-corruption, and industrialization. And these are among the issue-based campaign subjects the electorates expects to hear which sums up to $41.3 \%$. But the nonissue-based subjects like name-calling (16.4\%), allegations (21.5\%) and partisanship (20.7\%) took more of the statements, which together made up $58.6 \%$ of the entire reports. This implies that more of the statements during the political campaign were not issue-based.

Research Question Four: How were the stories on issue-based political statements and campaigns in Nigeria's politics placed in the newspapers?

\begin{tabular}{|c|c|c|c|c|c|c|c|c|c|c|c|}
\hline \multirow[b]{2}{*}{$\begin{array}{l}\text { Promine } \\
\text { nce }\end{array}$} & \multicolumn{3}{|c|}{ November } & \multicolumn{2}{|c|}{ January } & \multicolumn{4}{|c|}{ February } & \multirow[b]{2}{*}{$\begin{array}{l}\text { Tot } \\
\text { al }\end{array}$} & \multirow[b]{2}{*}{$\begin{array}{l}\text { Perce } \\
\text { nt }(\%)\end{array}$} \\
\hline & $\begin{array}{l}\text { Vang } \\
\text { uard }\end{array}$ & $\begin{array}{l}\mathbf{P u} \\
\mathrm{nc} \\
\mathrm{h}\end{array}$ & $\begin{array}{l}\text { To } \\
\text { tal }\end{array}$ & $\begin{array}{l}\text { Vang } \\
\text { uard }\end{array}$ & $\begin{array}{l}\mathrm{Pu} \\
\mathrm{nc} \\
\mathrm{h}\end{array}$ & $\begin{array}{l}\text { To } \\
\text { tal }\end{array}$ & $\begin{array}{l}\text { Vang } \\
\text { uard }\end{array}$ & $\begin{array}{l}\mathbf{P u} \\
\mathrm{nc} \\
\mathrm{h}\end{array}$ & $\begin{array}{l}\text { To } \\
\text { tal }\end{array}$ & & \\
\hline $\begin{array}{l}\text { Front } \\
\text { page }\end{array}$ & 12 & 12 & 24 & 5 & 8 & 13 & 3 & 4 & 7 & 44 & 37.9 \\
\hline $\begin{array}{l}\text { Inside } \\
\text { page }\end{array}$ & 10 & 12 & 22 & 14 & 12 & 26 & 14 & 10 & 24 & 72 & 62.1 \\
\hline $\begin{array}{l}\text { Centre } \\
\text { page }\end{array}$ & 0 & 0 & 0 & 0 & 0 & 0 & 0 & 0 & 0 & 0 & 0 \\
\hline $\begin{array}{l}\text { Back } \\
\text { page }\end{array}$ & 0 & 0 & 0 & 0 & 0 & 0 & 0 & 0 & 0 & 0 & 0 \\
\hline Total & 22 & 24 & 46 & 19 & 20 & 39 & 17 & 14 & 31 & 116 & 100 \\
\hline
\end{tabular}

Table 4: Placement of Stories on Political Statements

From Table 4, it can be understood that none of the statements appeared on the centre nor back page but only on the front and inside page. The number of stories that appeared on the front page (37.9) among the 116 reports on political statements and campaigns in Nigeria's politics, 
speaks of the attention that accorded the issue. It is the cover page stories that are often used to sell the newspaper.

Research Question Five: What is the directionality of newspaper reports on issue-based political statements and campaigns in Nigeria's politics?

\begin{tabular}{lcccccccccccc}
\hline \multirow{2}{*}{$\begin{array}{l}\text { Directionalit } \\
\text { y }\end{array}$} & \multicolumn{3}{c}{ November } & \multicolumn{4}{c}{ January } & \multicolumn{3}{c}{ February } & Tot & Perce \\
\cline { 2 - 10 } & $\begin{array}{c}\text { Vangu } \\
\text { ard }\end{array}$ & $\begin{array}{c}\text { Pun } \\
\text { ch }\end{array}$ & $\begin{array}{c}\text { To } \\
\text { tal }\end{array}$ & $\begin{array}{c}\text { Vangu } \\
\text { ard }\end{array}$ & $\begin{array}{c}\text { Pun } \\
\text { ch }\end{array}$ & $\begin{array}{c}\text { To } \\
\text { tal }\end{array}$ & $\begin{array}{c}\text { Vangu } \\
\text { ard }\end{array}$ & $\begin{array}{c}\text { Pun } \\
\text { ch }\end{array}$ & $\begin{array}{c}\text { To } \\
\text { tal }\end{array}$ & $\begin{array}{c}\text { al } \\
\text { nt (\%) }\end{array}$ \\
\hline Favourable & 2 & 3 & 5 & 3 & 2 & 5 & 1 & 0 & 1 & 11 & 9.5 \\
Neutral & 16 & 18 & 34 & 14 & 16 & 30 & 14 & 13 & 27 & 91 & 78.4 \\
Unfavourable & 4 & 3 & 7 & 2 & 2 & 4 & 2 & 1 & 3 & 14 & 12.06 \\
\hline Total & $\mathbf{2 2}$ & $\mathbf{2 4}$ & $\mathbf{4 6}$ & $\mathbf{1 9}$ & $\mathbf{2 0}$ & $\mathbf{3 9}$ & $\mathbf{1 7}$ & $\mathbf{1 4}$ & $\mathbf{3 1}$ & $\mathbf{1 1 6}$ & $\mathbf{1 0 0}$ \\
\hline
\end{tabular}

Table 5: Direction of Reports on Political Statements

Table 5 highlights that most of the reports were neutral in the presentation, given the $78.4 \%$. This implies that the stories reported political statements with less supportive or unsupportive approach.

\section{SOME POLITICAL STATEMENTS ON ISSUES IN THE DAILIES}

The data presented in above in Table 3 reveals that few of the statements were on issue-based subjects whereas more of the speeches were on non-issue-base. Some of the issue-based statements are as follows:

\section{Restructuring 2019 Presidency: We'll back only candidates that support restructuring - Aare Adams}

As the 15th Aare Onakakanfo of Yoruba Land, I [Gani Adams] must not be partisan, every son and daughter of Yoruba Land has every right to visit me. Only a presidential candidate that has passion and believes in the restructuring of Nigeria will be supported.

By Dupo Akinrefon, Vanguard, November 26, 2018, p. 11

\section{Restructuring: Buhari, Osinbajo deceitful, say Afenifere, Ohaneze}

President Muhammadu Buhari and Vice President Yemi Osinbajo on Tuesday came under attack over their separate remarks on the ongoing call for restructuring of the country.

"It is either these people are slow at learning or they cannot understand issues around them. We have made the issues very clear on what the call for restructuring is about" (Yinka Odumakin).

By O. Fabiyi, O. Adetayo, O. Atoyebi \& O. Aluko, Punch, Nov. 14, 2018, 


\section{Economy \& Atiku will reduce fuel price, say PDP}

Transportation The Peoples' Democratic Party has said its presidential candidate has worked out a pricing template that will immediately crash the pump price of fuel in the country.

By Olusola Fabiyi, Punch, November 2, 2018, p. 10

\section{Atiku promises to revive Warri Seaport, complete Second Niger Bridge}

The presidential candidate of the PDP, Alhaji Atiku, has promised to revive the Warri Seaport in Delta State.

By Ochei Matthew, Punch February 1, 2019, p.7

\section{Infrastructure Sanwo-Olu 'll not abandon ongoing projects, says Ambode}

$\&$ Health "I am so excited about the fact that Mr. Sanwo-Olu has actually come out here and he has issued a promissory note and what that means is that we are going to have a government of continuity" (Akinwunmi Ambode).

By Oladimeji Ramon, Punch, November 23, 2018, p. 6

Imo Guber: Ohakim promises to reduce mortality rate by $60 \%$ The Imo state governorship candidate of the Accord Party, Ikedi Ohakim, yesterday promised to implement a policy he said would reduce the mortality rate in the state by 60 per cent.

By Chinonso Alozie, Vangaurd, fanuary 9, 2019, p. 15

The above excerpts are some of the political statements made during the 2019 general elections campaign period. These were part of the issuebased speeches by the candidates and their parties. It is expected that campaigns should serve as platforms for aspirants to inform the electorates on what they would do if given the opportunity. Besides some of the accounts of issue-based statements by politicians reported in the dailies, there were more non-issue-based statements, as indicated in the data. Some of such include: 
Name-Calling Okorocha, Yari, Amosun, suffering change trauma, Oshiomhole National chairman of the ruling All Progressive Congress, APC, Comrade Adams Oshiomhole, has said that the three govs opposed to his conduct of party primaries in their states were behaving like drug addicts suffering from 'withdrawal symptoms'.

By Omeiza Ajayi, Vanguard, November 2, 2018, pp. $1 \& 41$

\section{Buhari no match for Atiku, PDP - Atiku's leading gang of mercantile politicians, APC responds}

Ahead of the 2019 presidential election, Peoples Democratic Party, PDP, has challenged President Muhammadu Buhari to a live, one-onone debate with its candidate, Atiku Abubakar, on critical sectors of the nation's economy.

By Dirisu Yakubu \& Omeiza Ajayi, Vanguard, November 26, 2018, p. 8

\section{Tinubu attacks Atiku, says ex-VP not fit for president}

The national leader of the APC, Bola Tinubu, has said former VicePresident Atiku Abubakar does not deserve another shot at power because he blew his opportunity during his eight years reign under former President Olusegun Obasanjo.

By Oladimeji Ramon, Punch, Fanuary 9, 2019, p. 40

Allegations Presidential poll: Atiku's integrity questionable - Tinubu National leader of the All Progressives Congress, APC, Asiwaju Bola Tinubu, yesterday, said unlike President Muhammadu Buhari, the integrity of presidential candidate of Peoples Democratic Party, PDP, Atiku Abubakar is questionable.

"Leave a naira on the table with Buhari in the room, you will find the naira on the table when you return...With Atiku, things are more nuanced...His compass has four models pointing in different directions at the same time" (Tinubu).

$$
\text { By Dapo Akirefon, Vanguard, January 9, 2019, p. } 11
$$

\section{Buhari using govt funds for campaign, says Atiku}

The presidential candidate of the Peoples Democratic Party, Atiku Abubakar, has that President Muhammadu Buhari of the All Progressive Congress, is using government funds for his presidential campaign.

By Success Nwogu, Punch, Fanuary 11, 2019, p. 7

\section{Buhari, APC can't be trusted, says Atiku at Lagos rally}

The presidential candidate of the Peoples Democratic Party, Alhaji Atiku Abubakar, has said President Muhammadu Buhari and his party, the Al Progressive Congress, can no longer be trusted because they have not kept any of the promises they made to Nigerians while soliciting their votes four years ago.

By Femi Makinde, Punch, February 13, 2019, p. 7 


\section{Partisanship 2019 Imo guber: I'll support Nwosu if he joins another party - Okorocha}

Imo State governor Rochas Okorocha, yesterday said he would support his son-in-law Mr. Uche Nwosu, for the governorship race in Imo, should he (Nwosu) join another political party.

By Chinonso Alozie, Vanguard, November 28, 2018, p. 8

Oshiomhole: Once you join the APC, your sins are forgiven The National chairman of the All Progressive Congress, Adams Oshiomhole, urged members of opposition party to join the APC so that their sins could be forgiven.

By S. Nwogu, T. Onojeghen \& A. Peter, Punch, January 18, 2019, pp. $1 \& 2$

\section{Re-list us, or no polls in Rivers - APC candidates}

Candidates of All Progressive Congress, APC, for the 2019 elections in Rivers State have said they will not allow elections to hold in the state if Independent National Electoral Commission, INEC, does not relist them in the ballot for the general election.

By E. Yafugborhi \& D. Iheanachor, Vanguard, February 15, p. 1

In the above statements, it is clear that the issues raised against the individuals mentioned are nothing but personal sentiments rather than topical issues of public interest. By describing Okorocha, Yari and Amosun as suffering from "withdrawal symptoms", the speaker is invariably saying that they are mentally weak and short of right thinking mind. On the second statement, the intention is to tag the candidate and his party as commercially minded persons who only want to exploit the people. And in the last statement, the speaker wants the electorate not to even mention the name because the person is not qualified to start with. All these expressions were geared to discrediting the individuals. The allegations on integrity, misuse of public fund and lack of trust are also geared towards smearing the personalities. The partisanship depict how attached the individuals are such that it is only what concerns them that matters.

\section{DISCUSSION OF FINDINGS}

\section{Frequency of Reports on Political Statements and Campaigns}

From the findings in Table 1, it was discovered that more political statements were made before the date of the election as the newspapers recorded decline in reportage on the issue, close to the election. That is, while the dailies reported much of political statements within the period, the number of reports dropped from $37.06 \%$ to $26.7 \%$ by the last month of 
the campaign. Corroborating this qualitative data were the statements cited above, which also indicated that more non-issue-based speeches were uttered at the earlier part of the campaign period. This indicates that the press follow issues and political actors as they move such that when they raise their voices, the media highlights such and when they keep silent, the same is reflected in the reports. Asiru, Ogutu and Orwenjo (2018) found out that the press do accord attention to political actors in their reportage. This finding supports the Agenda Setting theory that the press set the tone for discussion of issues.

\section{Story Types on Political Statements and Campaigns}

Among the types of stories, the findings show that almost all the reports came as straight news $(99.1 \%)$, which meant that it was the statements made by the politicians that formed a good part of the newspaper reports. This brings out the principle of salience in the agenda theory of the media. The newspapers were able to emphasise that stories about statements made by politicians during the period were newsworthy and should be emphasized.

\section{Kinds of Political Statements in Campaigns}

The study had two major classes of indicators on the kinds of statements. It was found out that there were less of issue-based statements given that the sum of such is $41.3 \%$ compared to the non-issue-based statements that totaled $58.6 \%$. It is then clear what was observed during the 2019 electioneering campaign were statements devoid of developmental plans but full of personal sentiments. Besides the cited statements above on name-calling, allegations and partisanship, there were others like "Stop donating like Father Christmas, attend to Nigerians, Atiku tells Buhari (Punch newspaper, 2018, Nov. 5, p. 53); "Buhari is too weak to lead Nigeria, says PDP" (Punch newspaper, Jan. 23, 2019, p. 3); and "I won't disappoint you like APC, Atiku" (Vanguard newspaper, Feb. 13, p. 10). This findings aligns with NOI Polls (2015) in which it was found out that about $57 \%$ of adult Nigerians believe that political campaigns do not address important issues in the country. The development media theory underlines that the press should highlight development issues in the society. This means that more of the reports in the dailies should be on statements that are issue-based in subsequent periods. The projection of candidates who make issue-based statements could influence voting. 


\section{Placement of Stories on Issue-based Political Statements}

The findings from the study show that the reports on the political statements appeared on the front (37.9\%) and inside pages (62.1) only. Basically, the back page of newspapers are given to sports and special features such that it does not take regular news stories. But the prominence is predicated on fact that the reports made the cover pages and in most cases, the banner headlines. Stories like "Okorocha, Amosun attack Oshiomhole afresh - his leadership has cost APC 5 million members, says Imo gov - we'll resist any bid to hand Ogun over to a rapacious cabal - Ogun gov" (Vanguard newspaper, 2018, Nov. 2, p. 1) and "Elections: Obasanjo bombs Buhari again - says he's planning to rig polls, behaving like Abacha" (Vanguard newspaper, 2019, Jan. 21, p. 1) are among the numerous that appeared on the cover page. This finding demonstrates the agenda setting theory that the emphasis media places on certain issues based on placement or coverage could influence the importance the audience attach to such (Scheufele \& Tewksbury, 2007).

\section{CONCLUSION}

Because Nigeria's electoral process is now more dynamic than in earlier years with the nature of competitions among political parties, politicians explore ways to woo voters during election campaigns. In the course of this, political statements are often made at different forums and platforms. The expectation is that campaigns should address issues that affect the country, but in some instances the comments are directed at personal affairs and matters of less public interest. The press exists to report issues for voters' enlightenment. This paper examined newspaper coverage of issue-based political statements and campaigns in Nigeria's electoral process. The paper found out that while there were coverage over some national issues like restructuring, security, corruption, economy, unemployment, and electricity, the greater volume of reports of political statements in newspapers were not issue-based. There is the need for the press to pay less attention to matters that would not serve to educate voters appropriately.

\section{RECOMMENDATIONS}

Drawing from the findings put forward, the study therefore recommends that: 
1. Given that during the electioneering period much attention was accorded to political statements, there is the need for the press to balance issues of national interest along with current developments in order not to silence other matters of public interest.

2. Literate Nigerians need to react to political statements through articles, letters, etc. for dailies because these were almost non-existing on the issue within the period.

3. Nigerians need to ask politicians questions based on issues of national or public importance as a means of reducing non-issuebased statements. In the same vein, the press use the editorials to speak against non-issue-based campaigns.

4. The press need to highlight more of issue-based political statements on the cover page rather than those that would create panic and disaffection.

\section{CONTRIBUTION TO KNOWLEDGE}

Academically, this paper is a seminal effort, that is, first attempt to analyse the political statements made by politicians in the most recent general elections held in Nigeria. In practice, it gives the public a picture of the kind of statements made by leaders during the 2019 electioneering campaign, which would aid future development initiatives.

References

Adeleke, F. (2006). Political behaviour among the rural dwellers in selected areas of Osun State. M.Sc Project: Department of Sociology, University of Ibadan, Nigeria.

Adibe, J. (2015). Fayose's advert: Offensive or hate speech? Adapted from a paper presented at a roundtable on hate speech organized by the Kukah Centre, Abuja, January 27.

Anaeto, S. G., Onabanjo, O. S. \& Osifeso, J. B. (2008). Theories and models of communication. Maryland: African Renaissance Books Inc.

Anorue, L. I., Obayi, P. M. \& Onyebuchi, C. A. (2012). The mass media, gender balance and politics in Nigeria: An assement. AFRREV LALIGENS: An International Journal of Language, Literature and Gender Studies Bahir Dar, Ethiopia, 1(3), 1435.

Asiru, H.T.; Ogutu, E.A. \& Orwenjo, D.O. (2018). Event and actors representation in selected Nigerian daily newspapers. Ghana fournal of Linguistics, 7(1), 84-104. Doi: 10.4314 /gjl.v7i1.4

Baran, S.J. \& Davis, D.K. (2009). Mass communication theory: Foundations, ferment, and future (5th ed.). Boston MA: Wadsworth Cengage Learning. 
Carkoglu, A., Baruh, L., \& Yildirim, K. (2014). Press-party parallelism and polarization of news media during an election campaign: The case of the 2011 Turkish elections. The International fournal of Press/Politics, 19(3), 295-317. Doi:

10.1177/1940161214528994

Chiluwa, I. (2011). Media representation of Nigeria's joint military task force in the Niger Delta crisis. International fournal of Humanities and Social Science, 1(9), 197-208.

Devaney, H. (2013). Perceptions of media bias: Viewing the news through ideological cues. A Senior Honor Thesis, University of California, San Diego.

Dimitrova, D.V.; Shehata, A.; Stromback, J. \& Nord, L.W. (2014). The effects of digital media on political knowledge and participation in election campaigns: Evidence form panel data. Communication Research, 4(1), 95-118. Doi: $10.1177 / 0093650211426004$

Egburonu, S. \& Odufowokan, D. (2018, November 18). 2019: Issues that will shape presidential campaigns. The Nation. Retrieved from:

http://thenationonlineng.net/2019-issues-will-shape-presidential-campaigns/

Hampl, M. (2017). The representation of social actors in conflicting discourse. In M. Ferenčík \& K. Bednárová-Gibová (Eds.) Discourse and Ideology: Studies in Critical Stylistics (56-69). Prešov. Retrieved from:

https://www.pulib.sk/web/kniznica/elpub/dokument/Ferencik4/subor/Hampl.pd $\underline{\mathrm{f}}$

Held, D. (2006). Models of democracy. Stanford: Stanford University Press.

Ibraheem, I.A., Ogwezzy-Ndesikka, O. A. \& Tejumaiye, A. (2015). Beyond influence: Media and the 2015 presidential election. Retrieved from: www.inecnigeria. org/.../2015/

IDEA, International Institute for Democracy and Electoral Assistance (2017). Elections, electoral systems and party systems: A resource guide. Stockholm: Author.

Iheanacho, E. (2019, October 10). Case for issue based election campaign. Leadership. Retrieved from: https://leadership.ng/2018/10/27/case-for-issue-based-electioncampaign/

Kerlinger, F.N. (2000). Foundations of behavioural research (4th ed.). New York: Holt, Rinehart \& Winston.

Kukah, H. (2015). Hate speech, social media and the 2015 election. Retrieved from: pointblanknews.com/pbn/.../hate-speech-social-media-2015-election/

McQuail, D. (2010). McQuail's mass communication theory (6th ed.). London: SAGE Publications Ltd.

Mrabure, K.O. (2016). Counteracting hate speech and the right to freedom of expression in selected jurisdictions. Nnamdi Azikiwe University fournal of International Law and Jurisprudence, (7), 160-169.

Musbeh, M.A. (2018). Managing elections: Definition and classification of election management bodies. SSRN Electronic fournal. Doi: 10.2139/ssrn.2271279 
NOI Polls (2015, January 27). Nigerians claim that political campaigns are not addressing key issues in the country: Countdown to 2015 election poll series. Author. Retrieved from: https://www.noi-polls.com/root/index.php? pid=221\&parentid=12\&ptid $=1$

Ojebuyi, B.R. \& Chukwunwike, A.C. (2018). Gender bias in media representation of political actors: Examples from Nigeria's 2015 presidential election. Legon fournal of the Humanities, 29(1), 195-225. Doi: 10.4314/ljh.v29i1.8

Okorie, M. (2016). The widening gap of gender inequality in Nigerian politics: Advocating a quota system approach. AFRREV IfAH: An International fournal of Arts and Humanities, 5(2), 251-260.

Scheufele, D.A. \& Tewksbury, D. (2007). Framing, agenda setting, and priming: The evolution of three media effects models. Fournal of Communication, (57), 9-20. Doi: $10.1111 / \mathrm{j} .0021-9916.2007 .00326 . \mathrm{x}$

Sete, T.A. (2018). Intra party democracy in Ethiopia: Towards a regulatory regime. Haramaya Law Review, (7), 22-47.

Sobowale, D. (2019, January 5). Election campaigns, issues and personalities. The $\mathrm{Na}-$ tion. Retrieved from: http://thenationonlineng.net/election-campaigns-issuespersonalities/

Unah, L. (2019). The key issues shaping Nigeria's presidential election. TRTWorld. Retrieved from: https://www.trtworld.com/magazine/the-key-issues-shapingnigeria-s-presidential-elections-23995

Wahl-Jorgensen, K. \& Hanitzsch, T. (2009). The handbook of journalism studies. New York, NY: Routledge.

Список литературы

Adeleke, F. (2006). Political behaviour among the rural dwellers in selected areas of Osun State. M.Sc Project: Department of Sociology, University of Ibadan, Nigeria.

Adibe, J. (2015). Fayose's advert: Offensive or hate speech? Adapted from a paper presented at a roundtable on hate speech organized by the Kukah Centre, Abuja, January 27.

Anaeto, S. G., Onabanjo, O. S. \& Osifeso, J. B. (2008). Theories and models of communication. Maryland: African Renaissance Books Inc.

Anorue, L. I., Obayi, P. M. \& Onyebuchi, C. A. (2012). The mass media, gender balance and politics in Nigeria: An assement. AFRREV LALIGENS: An International Journal of Language, Literature and Gender Studies Bahir Dar, Ethiopia, 1(3), 1435.

Asiru, H.T.; Ogutu, E.A. \& Orwenjo, D.O. (2018). Event and actors representation in selected Nigerian daily newspapers. Ghana fournal of Linguistics, 7(1), 84-104. Doi: 10.4314 /gjl.v7i1.4

Baran, S.J. \& Davis, D.K. (2009). Mass communication theory: Foundations, ferment, and future (5th ed.). Boston MA: Wadsworth Cengage Learning. 
Carkoglu, A., Baruh, L., \& Yildirim, K. (2014). Press-party parallelism and polarization of news media during an election campaign: The case of the 2011 Turkish elections. The International fournal of Press/Politics, 19(3), 295-317. Doi:

10.1177/1940161214528994

Chiluwa, I. (2011). Media representation of Nigeria's joint military task force in the Niger Delta crisis. International fournal of Humanities and Social Science, 1(9), 197-208.

Devaney, H. (2013). Perceptions of media bias: Viewing the news through ideological cues. A Senior Honor Thesis, University of California, San Diego.

Dimitrova, D.V.; Shehata, A.; Stromback, J. \& Nord, L.W. (2014). The effects of digital media on political knowledge and participation in election campaigns: Evidence form panel data. Communication Research, 4(1), 95-118. Doi: $10.1177 / 0093650211426004$

Egburonu, S. \& Odufowokan, D. (2018, November 18). 2019: Issues that will shape presidential campaigns. The Nation. Retrieved from:

http://thenationonlineng.net/2019-issues-will-shape-presidential-campaigns/

Hampl, M. (2017). The representation of social actors in conflicting discourse. In M. Ferenčík \& K. Bednárová-Gibová (Eds.) Discourse and Ideology: Studies in Critical Stylistics (56-69). Prešov. Retrieved from:

https://www.pulib.sk/web/kniznica/elpub/dokument/Ferencik4/subor/Hampl.pd $\underline{\mathrm{f}}$

Held, D. (2006). Models of democracy. Stanford: Stanford University Press.

Ibraheem, I.A., Ogwezzy-Ndesikka, O. A. \& Tejumaiye, A. (2015). Beyond influence: Media and the 2015 presidential election. Retrieved from: www.inecnigeria. org/.../2015/

IDEA, International Institute for Democracy and Electoral Assistance (2017). Elections, electoral systems and party systems: A resource guide. Stockholm: Author.

Iheanacho, E. (2019, October 10). Case for issue based election campaign. Leadership. Retrieved from: https://leadership.ng/2018/10/27/case-for-issue-based-electioncampaign/

Kerlinger, F.N. (2000). Foundations of behavioural research (4th ed.). New York: Holt, Rinehart \& Winston.

Kukah, H. (2015). Hate speech, social media and the 2015 election. Retrieved from: pointblanknews.com/pbn/.../hate-speech-social-media-2015-election/

McQuail, D. (2010). McQuail's mass communication theory (6th ed.). London: SAGE Publications Ltd.

Mrabure, K.O. (2016). Counteracting hate speech and the right to freedom of expression in selected jurisdictions. Nnamdi Azikiwe University fournal of International Law and Jurisprudence, (7), 160-169.

Musbeh, M.A. (2018). Managing elections: Definition and classification of election management bodies. SSRN Electronic fournal. Doi: 10.2139/ssrn.2271279 
NOI Polls (2015, January 27). Nigerians claim that political campaigns are not addressing key issues in the country: Countdown to 2015 election poll series. Author. Retrieved from: https://www.noi-polls.com/root/index.php? pid=221\&parentid=12\&ptid $=1$

Ojebuyi, B.R. \& Chukwunwike, A.C. (2018). Gender bias in media representation of political actors: Examples from Nigeria's 2015 presidential election. Legon fournal of the Humanities, 29(1), 195-225. Doi: 10.4314/ljh.v29i1.8

Okorie, M. (2016). The widening gap of gender inequality in Nigerian politics: Advocating a quota system approach. AFRREV IfAH: An International fournal of Arts and Humanities, 5(2), 251-260.

Scheufele, D.A. \& Tewksbury, D. (2007). Framing, agenda setting, and priming: The evolution of three media effects models. Fournal of Communication, (57), 9-20. Doi: $10.1111 / \mathrm{j} .0021-9916.2007 .00326 . \mathrm{x}$

Sete, T.A. (2018). Intra party democracy in Ethiopia: Towards a regulatory regime. Haramaya Law Review, (7), 22-47.

Sobowale, D. (2019, January 5). Election campaigns, issues and personalities. The $\mathrm{Na}-$ tion. Retrieved from: http://thenationonlineng.net/election-campaigns-issuespersonalities/

Unah, L. (2019). The key issues shaping Nigeria's presidential election. TRTWorld. Retrieved from: https://www.trtworld.com/magazine/the-key-issues-shapingnigeria-s-presidential-elections-23 995

Wahl-Jorgensen, K. \& Hanitzsch, T. (2009). The handbook of journalism studies. New York, NY: Routledge. 